\title{
Dialog Josepha Rotha z Alfredem Döblinem w Żydach na tułaczce i Listach z Polski
}

\author{
Joseph Roth in Dialogue with Alfred Döblin: The Wandering Jews and Briefe \\ aus Polen
}

Abstract: Alfred Döblin and Joseph Roth wrote their texts about Poland and Polish Jews at the same time (1924-1927). The article not only compares their works, but also documents that Roth might have felt called upon by Döblin to write essays The Wandering Jews. He was indebted to Döblin for giving him the courage to publicly admit his East-Jewish roots and was inspired by his subjective, personal narrative. In several passages he refers to Journey in Poland and enters into dialogue with Döblin.

Keywords: Alfred Döblin, Joseph Roth, Images of Poland, Images of Polish Jews, German Literature

Streszczenie: Alfred Döblin i Joseph Roth napisali swoje teksty o Polsce i polskich Żydach w tym samym czasie (1924-1928). Artykuł nie tylko porównuje ich utworów, lecz także przedstawia uzasadnienie tezy, że Roth mógł się czuć wezwany przez Döblina do napisania esejów Żydzi na tutaczce. Zawdzięczał Döblinowi odwagę publicznego przyznania się do jego wschodniożydowskich korzeni i został przez niego zainspirowany do subiektywnej, osobistej narracji. W kilku miejscach nawiązuje do Podróży po Polsce i prowadzi z Döblinem dialog.

Słowa kluczowe: Alfred Döblin, Joseph Roth, obraz Polski, obraz polskich Żydów, literatura niemiecka

Teksty podróżnicze Alfreda Döblina i Josepha Rotha o Polsce powstały mniej więcej w tym samym czasie - między rokiem 1924 a 1928 - i już choćby z tego powodu skłaniają do porównań. Ponieważ obaj pisarze się znali ${ }^{1}$, a Roth przeczytał i zrecenzował Podróż po Polsce Döblina zaraz po jej ukazaniu się

${ }^{1}$ Obaj, Roth i Döblin, byli członkami „Grupy 1925”, założonej przez pisarzy zamieszkałych w Berlinie. Poza tym Roth przez jakiś czas wysyłał swoją żonę na terapię do Döblina. 
w październiku 1925 roku $^{2}$, zasadnym zdaje się pytanie, w jakim stopniu został przez nią zainspirowany i czy w swoich później powstałych dziełach o Polsce i o polskich Żydach prowadził z Döblinem dialog lub może nawet polemikę. Zamierzam więc zweryfikować istniejące w badaniach nad Rothem domniemanie, że Żydzi na tutaczce stanowią odpowiedź na relację z podróży Döblina ${ }^{3}$.

Pierwsza seria artykułów Rotha o Polsce pod tytułem Podróż po Galicji ukazała się w listopadzie 1924 roku we „Frankfurter Zeitung”, kiedy Alfred Döblin był akurat w Polsce. Teksty te stanowiły owoc podróży, którą Roth odbył kilka miesięcy wcześniej. Trudno ocenić, czy paralele istniejące między nimi a wydaną rok później książką Döblina Podróż po Polsce przypisać należy inspiracji czy też wspólnej tematyce podjętej przez obydwu podróżników. Zarówno Roth, jak i Döblin krytykują politykę polskiego rządu wobec mniejszości narodowych, podkreślają także znaczenie wojska w młodym polskim państwie, jednak prezentowane przez nich obrazy nowopowstałego kraju bardzo się od siebie różnią. Podczas gdy u Rotha „niedawno wzmocniona, przez najnowszy bieg historii poniekąd potwierdzona polska świadomość narodowa” wspomniana jest tylko w kontekście polityki wobec mniejszości ${ }^{4}$, Döblin bardziej interesuje się problemami, przed którymi stoi polskie państwo, a sytuację Polski lokuje w centrum swoich rozważań. Inna różnica między obiema relacjami z podróży polega według Vereny Dohrn na tym, że Joseph Roth idealizował Lwów, widząc w nim „wciąż jeszcze [istniejącą - dop. M.B.] barwną narodową różnorodność kosmopolitycznego galicyjskiego miasta”, natomiast Döblin do-

2 O powstaniu książki Döblina zob. M. Brandt: „Podróż po Polsce” Alfreda Döblina. Kilka uwag o genezie tekstu, tłum. M. Szalsza, „Konteksty Kultury” 2017, z. 2, s. 138-153, www.ejournals.eu/Konteksty_Kultury/2017/Tom-14-zeszyt-2/art/10242, dostęp: 17.03.2019.

${ }^{3}$ Zob. E. Raffel, Vertraute Fremde. Das östliche Judentum im Werk von Joseph Roth und Arnold Zweig, Tübingen 2002, s. 110. Zob. też wzmiankowane poniżej publikacje Marka H. Gelbera i Michaela Brennera. Skupiam się tu na literaturze zajmującej się relacją między Rothem i Döblinem, a ważne polskojęzyczne pozycje (włącznie z publicystyka) na temat obrazu Polski i Żydów polskich u obu pisarzy to: M. Dziuba, „To już prawie caty polski Lublin”. Zapiski Alfreda Döblina z podróży do Polski, „Scriptores. Pamięć. Miejsce. Obecność” 2003, nr 1 (27), s. 140-145; H. Grynberg, Postowie [w:] A. Döblin, Podróż po Polsce, tłum. A. Wołkowicz, Kraków 2000, s. 311-317; G. Kwiecińska, Z Alfredem Döblinem w Drugiej Rzeczypospolitej, „Literatura na Świecie” 1994, nr 6, s. 84-93; P. Matywiecki, Początek podróży do końca, „Midrasz” 2001, nr 2, s. 46-48; J. Wittlin, Podróż Döblina po Polsce, „Wiadomości Literackie” 1927, nr 9, s. 1; J. Golec, Literackie powroty do ojczyzny. Joseph Roth i jego Galicja [w:] tegoż, Od Wiednia do Czerniowiec. Galicja i Bukowina w wybranych niemieckojezycznych utworach literackich, Lublin 2017, s. 45-72; P. Nowak, Ex oriente lux?, „Kronos. Metafizyka, kultura, religia” 2018, nr 1, s. 235-250; Samotny wizjoner. Joseph Roth we wspomnieniach przyjaciót, esejach krytycznych i artykułach prasowych, red. E. Jogałła, tłum. P. Krzak, Kraków-Budapeszt 2013 (szczególnie ostatni rozdział Joseph Roth widziany przez polskich przyjaciót, krytyków i badaczy, s. 365-442); R. Salvadori, Döblin i Roth we Lwowie, „Zeszyty Literackie” 1999, z. 2, s. 88-93 (Salvadori wychodzi jednak z mylnego założenia, że Döblin i Roth byli we Lwowie w tym samym czasie).

${ }^{4}$ J. Roth, Podróż po Galicji [w:] tegoż, Listy z Polski, tłum. M. Łukasiewicz, wstęp K. Czyżewski, Kraków-Budapeszt-Syrakuzy 2018, s. 35. 
strzegał, ,jak bardzo zaostrzył się narodowy konflikt między Polakami i Ukraińcami, przez który trzeciej grupie, czyli Żydom, znów grozi unicestwienie" 5 . Roth z pewnością również odnotował narodowe konflikty, których ofiarą padli Żydzi pod koniec wojny w pogromie lwowskim. Jeżeli mimo to zarysował nostalgiczny obraz miasta jako wspólnoty wielu kultur ${ }^{6}$, można dostrzec w tym projekt będący w opozycji do zaostrzających się nacjonalizmów w Europie Środkowej ${ }^{7}$. Döblin, który traktuje nacjonalizm równie krytycznie jak Roth, lecz w odróżnieniu od niego skupia uwagę właśnie na wytyczaniu granic między narodami, „zbiorowym bestiom” " państw narodowych przeciwstawia wolę i duchową siłę jednostki.

Na temat książki Döblina o Polsce Joseph Roth wypowiedział się niemal od razu w zamieszczonej we „Frankfurter Zeitung” recenzji z 31 stycznia 1926 roku. W literaturze przedmiotu spotkać można czasem opinię, że stanowiła ona odrzucenie książki ${ }^{9}$, chociaż w rzeczywistości tylko pierwsza jej część ma charakter krytyczny. Roth pisze, że Döblin nie ustrzegł się ,zachodnioeuropejskiej pychy cywilizacyjnej” i „atawizmów”, jako szczególnie uderzający przykład przytaczając jego charakterystykę Polek, zwłaszcza podkreślenie ich „niezwykłej pikanterii”"10. Wyraża obawę, że Döblin, gdy „pisze dowcipnie, powiedzmy, o marnym hotelu albo o kurorcie w Zakopanem", potwierdza niemieckie uprzedzenia do Europy Wschodniej ${ }^{11}$. Natomiast naszkicowany przez Döblina portret polskich Żydów zyskał uznanie, a nawet pochwałę Rotha:

Döblin widział Żydów bardzo stronniczo, co jest cnotą miłości. (...) Powinien był nazwać swoją książę Podróż do Żydów. Poznał ich lepiej niż zachodni syjoniści (...). Döblin przywiózł wiele wschodniożydowskich zwrotów (...). Dlatego ta książka przesycona jest atmosferą żydowską, a nie słowiańską ${ }^{12}$.

${ }^{5}$ V. Dohrn, Reise nach Galizien. Grenzlandschaften des alten Europa, Frankfurt am Main 1993, s. 77.

${ }^{6}$ J. Roth, Podróż po Galicji, dz. cyt., s. 37.

${ }^{7}$ M. Müller, Konstruierte Distanz - Zu Joseph Roths erster Galizien-Reportage „Leute und Gegend" [w:] Joseph Roth und die Reportage, red. T. Eicher, Heidelberg 2010, s. 182.

${ }^{8}$ A. Döblin, Podróż po Polsce, dz. cyt., s. 177.

9 Zob. M. Brenner, The Renaissance of Jewish Culture in Weimar Germany, New Haven 1996, s. 143; R. Dziergwa, Obraz Polski międzywojennej i konfrontacje z Kresami Wschodnimi II Rzeczypospolitej w utworach pisarzy niemieckich w latach 1918-1939, „Studia Historica Slavo-Germanica” 2004, t. 25, s. 117.

${ }^{10}$ Są one „dobrze obeznane ze strzałami Kupidyna. Noszą jasne, cieliste pończochy. Mają eleganckie buciki. Wszystkie są upudrowane, umalowane, uszminkowane. Zakład, że paryżanki też się pudrują, malują i szminkują, noszą jasne i cieliste pończochy oraz są niezwykle pikantne?”. Opisem mógł Döblin według Rotha potwierdzać znany z antypolskiej literatury stereotyp o niebezpiecznych Polkach. J. Roth, Döblin na Wschodzie [w:] tegoż, Listy z Polski, dz. cyt., s. $47-49$.

${ }_{11}$ Tamże, s. 49.

12 Tamże, s. 50. 
Dzięki tej książce i swojemu „znakomit[emu] przekonani[u]” Döblin udowodnit, „że spośród wielu niemieckich twórców on wtaśnie ma prawo podróżować do Polski” ${ }^{13}$. Słowa te wyszły spod pióra człowieka urodzonego w Galicji, od dzieciństwa obeznanego z kulturą polskich Żydów, można zatem potraktować je jako wyraz wysokiego uznania.

Dla Josepha Rotha Podróż po Polsce musiała stanowić wyzwanie, ponieważ Döblin tą relacją z podróży - zwłaszcza podróży do wschodnich Żydów i do Galicji - wkroczył na jego literackie terytorium ${ }^{14}$. Właściwie to Roth powinien był napisać książkę o Polsce i o polskich Żydach. Uczynił to też w roku 1927, wydając eseje Żydzi na tutaczce, które wraz z publikowanymi w roku 1928 we „Frankfurter Zeitung” Listami z Polski i planowanymi kolejnymi tekstami miaty stanowić obszerniejszy tom. Sugeruje to uwaga zamieszczona w liście, który po ukazaniu się zbioru esejów Roth napisał do Stefana Zweiga:

Wypowiedział się Pan w serdecznych słowach na temat mojej książki o Żydach. I ja dziękuję Panu serdecznie. W najbliższych latach zamierzam uzupełnić tę książkę i wydać ją na nowo. Być może będę mógł niektóre prace wstępne połączyć z moimi relacjami dla F.Z. ${ }^{15}$

Nad esejami Żydzi na tutaczce Roth pracował w latach 1925-1926, a więc w tym samym czasie, kiedy Döblin napisał i opublikował swoją książkę o Polsce (przeddruki pojedynczych rozdziałów ukazywały się od października 1924 do czerwca 1925 roku, sama zaś książka - jesienią roku 1925). Nawet jeżeli wcześniej już pisał o żydowskich emigrantach, widoczne w tych tekstach życzliwość wobec wschodnich Żydów i silne, emocjonalne ujmowanie się za nimi były czymś zupełnie nowym w publicystyce Rotha. Wilhelm von Sternburg wyjaśnia tę zmianę podróżą do Galicji odbytą latem roku 1924: „Podczas tej podróży doszło do refleksji nad własnym pochodzeniem, Roth prawdopodobnie na nowo uświadamiał sobie społeczne i religijne korzenie swojej egzystencji”'16. Powstałe wówczas reportaże nie zdradzają nam jednak nic na temat takiego zbliżenia, gdyż Żydzi występują w nich tylko marginalnie. Dlatego bardziej przekonująca zdaje się teza sformułowana przez Manfreda Müllera, że Roth w felietonach z Galicji z roku 1924 nie chciał mówić o swoim wschodniożydowskim pochodzeniu i że ukrywał swoją ,intymną znajomość rzeczy” - między innymi obdarzając narratora reportaży „zachodnioeuropejskim spojrzeniem” ${ }^{17}$. $\mathrm{Na}$

13 Tamże, s. 47.

14 W.F. Schöller, Alfred Döblin. Eine Biographie, München 2011, s. 503. Autor, nie odnosząc się do żadnego konkretnego tekstu, jest nawet zdania, że Roth mógł widzieć w Döblinie konkurenta.

15 J. Roth, S. Zweig, Glion bei Montreux, 8.09.1927 [w:] „Jede Freundschaft mit mir ist verderblich". Joseph Roth und Stefan Zweig. Briefwechsel 1927-1938, Göttingen 2011, s. 7.

${ }^{16}$ W. v. Sternburg, Joseph Roth. Eine Biographie, Köln 2009, s. 288.

${ }_{17}$ M. Müller, dz. cyt., s. 182. 
przykład narrator nie wspomina dzieciństwa spędzonego w Galicji, lecz stacjonowanie we Lwowie podczas pierwszej wojny światowej. Według Müllera Roth wybierał tu perspektywę byłego żołnierza, aby ułatwić zachodniemu czytelnikowi rozumienie sytuacji na Wschodzie, ponieważ Galicję w tym czasie często kojarzono z niedawno zakończoną wojną.

Według takiego ujęcia u podstaw książi Żydzi na tułaczce nie leży ponowne zbliżenie się do wschodniożydowskich korzeni, lecz raczej decyzja, by się do nich publicznie przyznać. Powstania tych esejów - inaczej niż to wyglądało w wypadku obu serii artykułów o Galicji i Polsce, opublikowanych we „Frankfurter Zeitung” - nie poprzedziły żadna podróż ani rekonesans. Odwagę publicznego wyznania swojej wschodniożydowskiej tożsamości Roth zawdzięczał być może Alfredowi Döblinowi: w recenzji jego książki o Polsce podkreślił „miłość”, z jaką autor wyraża się o pogardzanych na Zachodzie Żydach ze Wschodu, by na końcu przypisać mu też „śmiałą niesprawiedliwość, (...) sprawiedliwą odwagę"18. Już w tej recenzji Roth przyznaje się do swych wschodniożydowskich korzeni, występując jako ktoś, kto wie, czym są ,żydowskie zwroty”, i kto potrafi docenić dzieło niemieckiego pisarza o polskich Żydach, to znaczy ocenić, kto „spośród wielu niemieckich twórców (...) ma prawo podróżować do Polski”" ${ }^{19}$. Przypuszczalnie sytuacja konkurencji między obydwoma autorami, powstała w wyniku opublikowania Podróży po Polsce, skłoniła Rotha do wyznania swojej znajomości zagadnień dotyczących Żydów wschodnich i tym samym swojej przynależności do ich kultury. Subiektywność Döblina mogła ponadto zachęcić go do obrania osobistego tonu w Żydach na tułaczce. Claudia Sonino jest zdania, że Roth w tych esejach pozwolił sobie na swobodę subiektywnej wypowiedzi, którą wcześniej tak wychwalał u Döblina. Inaczej niż w reportażach z roku 1924, nie utrzymuje on już żadnego „bezpiecznego dystansu między sobą a Galicją":

Nie musi przemilczać swojego pochodzenia, nawet jeśli wciąż jeszcze pozostaje ono zawoalowane, przede wszystkim jednak może nareszcie pójść na całość i mówić o Żydach zachodnich i wschodnich - czyli też o sobie samym - ze stronniczością i gorliwością, które, jak twierdzi [w recenzji Podróży po Polsce-dop. M.B.] jest „cnotą miłości”20.

Uderzające jest to, że w powstałych zaledwie kilka lat później Listach z Pol$s k i$ autor wraca do narracji nieosobistej i do spojrzenia naznaczonego dystansem. Roth pisze w nich niekiedy - zdaniem Krzysztofa Lipińskiego - „jak ktoś obcy; zdarza mu się świadomie, a może nawet z zamierzeniem, patrzeć na

18 J. Roth, Döblin na Wschodzie, dz. cyt., s. 51.

19 Tamże, s. 47.

${ }^{20}$ C. Sonino, Exil, Diaspora, Gelobtes Land? Deutsche Juden blicken nach Osten, Berlin 2002, s. 142. 
sprawy swojskie niewtajemniczonym okiem niemieckiego korespondenta" ${ }^{21}$. David Bronsen wyjaśnia tę zmianę prywatną sytuacją Rotha, zwłaszcza troską o chorą żonę. Z jej powodu wszystko inne stało się dla niego nieważne, a Listy z Polski zamieniły się w „obowiązek”, przez co literacko nie dorastają do poziomu innych jego tekstów i pozostawiaja „,blade wrażenie”22. Również odrzucenie publikacji jego mocno osobistej książki o podróży do Francji Białe mia$s t a^{23}$ mogło przyczynić się do ponownego obrania obiektywnej narracji, która według Bronsena załamuje się tylko w jednym miejscu, kiedy Roth opowiada o ukraińskich pieśniach, znanych mu z dzieciństwa.

W Żydach na tutaczce i w Listach z Polski bez trudu można znaleźć paralele do książki Döblina o Polsce, lecz również tutaj niełatwo jest stwierdzić, czy wynikają one ze wspólnej tematyki i przedmiotu opisów, czyli charakterystyki Żydów wschodnich i Polski, czy też Roth prowadzi z Döblinem intertekstualny dialog. Idealizacja Żydów wschodnich jako wspólnoty skupionej na religijności i przeciwstawianej materialistycznemu, pod względem duchowym pustemu Zachodowi, nie jest specyficzna tylko dla tych dwóch pisarzy, lecz raczej wiąże ich z innymi niemiecko-żydowskimi autorami, takimi jak Arnold Zweig, Martin Buber czy Sammy Gronemann, i może być ogólnie traktowana jako topos w dyskursie o Żydach ze Wschodu na początku XX wieku ${ }^{24}$. Ponadto obaj autorzy podczas swoich podróży odwiedzili te same miasta (Lwów, Łódź) i okręg naftowy, pisali o mniejszościach narodowych i o życiu literackim w Polsce. Siła rzeczy musiało tu dochodzić do nakładania się treści.

Niewykluczone jednak, że Roth wybierał podobne tematy jak Döblin, żeby móc w ten sposób zaprezentować swoją szerszą wiedzę „insidera”. Na przykład w Listach z Polski na pierwszy plan mocno wysuwa się przekaz informacji, w którym Roth prawie całkiem odchodzi od charakterystycznej dla siebie narracji, od swego "proprium - mianowicie odzwierciedlania poznanych faktów w codziennych epizodach i scenkach rodzajowych" 25 - pomijając kilka wyjątków, jak wspomniana przez Bronsena relacja o kulturze ukraińskiej.

Niektóre fragmenty tekstów Rotha sugerują dialog z Döblinem. W pierwszej części Żydów na tutaczce, w której omówiona zostaje aktualna sytuacja wschodnioeuropejskich Żydów, Roth zdaje się prowadzić z Döblinem

21 K. Lipiński, Joseph Roth jako autor "polski” (Przektady i odbiór w Polsce) [w:] Samotny wizjoner, dz. cyt., s. 429.

22 D. Bronsen, Joseph Roth. Eine Biographie, Köln 1974, s. 311.

23 Zob. I. Sültemeyer-von Lips, „Städte haben viele Gesichter”. Wieviel Fiktion vertragen Reportage und Feuilleton? [w:] Joseph Roth - Städtebilder: Zur Poetik, Philologie und Interpretation von Stadtdarstellungen aus den 1920er und 1930er Jahren, red. S. Pesnel, E. Tunner, H. Lunzer, V. Lunzer-Talos, Berlin 2016, s. 31-59, szczególnie s. 49-59. Tam także wymieniono więcej literatury na ten temat.

24 Zob. S.E. Aschheim, Brothers and Strangers. The East European Jew in German and German Jewish Consciousness, 1800-1923, Madison 1982, s. 199. M. Brenner, dz. cyt., s. 143-147.

25 I. Sültemeyer-von Lips, dz. cyt., s. 44. 
rozmowę o syjonizmie, nawiązując do jego sformułowań. W zdaniu: „Tak, syjonizm i pojęcie narodowości mają w istocie - choć nie w intencji - charakter zachodnioeuropejski”"26 już choćby początkowa partykuła „tak” wskazuje na to, że autor odpowiada na jakieś zdanie poprzedzające. Może odnosić się to do stwierdzenia Döblina, że państwo narodowe, myślenie narodowe i również syjonizm to „zachodnie instytucje”, które nie dorastają do kondycji duchowej Żydów z Europy Wschodniej ${ }^{27}$. Roth zgadzał się z tą opinią: „Idea narodowa to koncept zachodni”"28. Przy całej krytyce ograniczania żydowskiej samoświadomości do myśli narodowej, która łączyła go z Döblinem, w odróżnieniu od niego dostrzegał w syjonizmie jedyne możliwe wyjście z obecnej trudnej sytuacji Żydów: „Na pewno lepiej jest samemu być narodem, niż być źle traktowanym przez inny naród. Ale to tylko bolesna konieczność" 29.

Przywołane fragmenty zawierają dialog z poglądami Döblina, inne zdają się nawiązywać do konkretnych scen z jego książki. Podobnie jak Döblin relacjonuje wizytę u cadyka Abrahama Mordechaja Altera w Górze Kalwarii, również Roth opowiada o odwiedzinach u cadyka, którego imienia i miejsca zamieszkania jednak nie wymienia. Inaczej niż u Döblina, jego narrator dobrze wie, w jaki sposób w dzień świąteczny mimo tłumu odwiedzających bez trudności dostać się do cadyka ${ }^{30}$. Zdaje się, że Roth chciał tu zademonstrować swoje obeznanie z kulturą wschodniożydowską na konkretnym przykładzie, a może także pokazać, że potrafi w zręczniejszy sposób, niż uczynił to Döblin, uzyskać dostęp do tak szacownej osoby.

Inna paralelna scena dotyczy obserwacji na temat najważniejszego żydowskiego święta, Jom Kipur. Pierwszoosobowy narrator Döblina jest wstrząśnięty tym, co ujrzał na cmentarzu w przeddzień Dnia Pojednania - były to głośno lamentujące kobiety, które mówiły do swoich zmarłych krewnych. Później prosi swego rozmówcę o wyjaśnienie tego zdarzenia, a odpowiedź go rozczarowuje. Żydowski „oświeceniowiec” „[p] otępia to, co mu opowiadam o warszawskim Święcie Zmarłych; ci ludzie mają tylko mętne wyobrażenie o tym, że dusza istnieje; on sam w ogóle nie lubi o tym słuchać" ${ }^{1}$. W obliczu tego opisu wywody Rotha na temat Jom Kipur zdają się oczekiwanym wyjaśnieniem, gdyż postrzeganie Döblina pojawia się w opisanym przez Rotha znaczeniu owego święta:

${ }^{26}$ J. Roth, Żydzi na tułaczce, tłum. M. Łukasiewicz, wstęp A. Taborska, Kraków-Budapeszt 2017, s. 28.

27 Zob. A. Döblin, Podróż po Polsce, dz. cyt., s. 128.

${ }^{28}$ J. Roth, Żydzi na tułaczce, dz. cyt., s. 29.

${ }^{29}$ Tamże, s. 32.

30 Jego strój sprawiał, że chasydzi brali go za ,jednego z budzących lęk urzędników tego kraju”, wobec czego ustępowali mu miejsca, a wpuszczający nawet podszedł do niego, żeby zapytać, jaką ma sprawę. Swoją prośbę o wpuszczenie poparł kilkoma banknotami. Ponadto, inaczej niż Döblin, Roth nie potrzebował tłumacza. Tamże, s. 47-50.

31 A. Döblin, Podróż po Polsce, dz. cyt., s. 229. 
Jom Kipur to nie Dzień Pojednania, lecz Dzień Pokuty (...). Za wszystkich zmarłych płoną teraz świece. (...) Umarłych od tego świata, żywych od zaświatów dzieli tylko jeden krok. (...) całe domy wypełnione są białymi kitlami, żywymi, którzy przebywają w innym świecie, zmarłymi, którzy ożywają, najmniejsza kropla nie zwilża zaschniętych warg i nie odświeża gardeł, które wykrzykują tyle skarg - kierowanych nie do tego świata, lecz do wyższego. (...) Strasznie jest wiedzieć, że w tym mieście nikt nie będzie dziś jadł ani pił. Wszyscy stali się nagle duchami, nabrali właściwości duchów ${ }^{32}$.

Mark H. Gelber jest zdania, że w opisach obu tych scen (wizyta u cadyka i Jom Kipur) Roth zawarł krytykę Döblina, który usiłował stworzyć dystans wobec zdarzeń - między innymi przez sięganie do źródeł historycznych, dokumentów i literatury naukowej. Roth natomiast chciał „emocjonalnie wstrząsnąć” czytelnikiem ${ }^{33}$. Jednak Döblin, umieszczając w bibliografii na końcu książki uwagę, że nie odwiedzał żadnych bibliotek, podkreślił, że w swojej relacji z podróży nie powołuje się na istniejące prace naukowe. Również Roth widział, że dla Döblina (pomimo kilku niezaprzeczalnie etnograficznych rysów jego relacji) przeżycie, spotkanie z rzeczywistością, było ważniejsze niż studium naukowe i na pewno nie poczytywał mu tego za złe, pisząc: „Na końcu wylicza książki, które czytał jako "materiał źródłowy«: nie ma wśród nich prac naukowych. Wskutek "nieznajomości rzeczy« jego sąd pozostał niezmącony” ${ }^{34}$. Co więcej, credo swojej własnej publikacji - a mianowicie „do przedmiotu podchodzi z miłością zamiast w duchu "naukowej rzeczowości«"35 - odnalazł również u Döblina, o którym stwierdził, że „widział Żydów bardzo stronniczo, co jest cnotą miłości” ${ }^{36}$. Różnica w narracji obu autorów, opisana przez Gelbera w kategoriach dionizyjskiej (Roth) i apollińskiej (Döblin), daje się lepiej ująć w inny sposób: Josephowi Rothowi zależało na tym, żeby przybliżyć zachodniemu czytelnikowi wschodniożydowską kulturę, którą sam poznał od wewnątrz. Uczynił to, stosując obrazy i wyjaśnienia, które służyły przekazaniu emocji i informacji. Döblin natomiast wkroczył z zewnątrz, z Zachodu, do kultury wschodniej, którą próbował zrozumieć i przeniknąć, tworząc montaż ze

32 J. Roth, Żydzi na tutaczce, dz. cyt., s. 51-52.

33 M.H. Gelber, "Juden auf Wanderschaft” und die Rhetorik der Ost-West-Debatte im Werk Joseph Roths [w:] Joseph Roth. Interpretation - Kritik - Rezeption. Akten des internationalen, interdisziplinären Symposions 1989, red. M. Kessler, F. Hackert, Tübingen 1990, s. 127-135, tu s. 130. Tezy Gelbera rozwinie Urszuła Górska: Retoryka ekspresji i etyczny problem asymilacji. Rozważania wokót eseju Josepha Rotha "Juden auf Wanderschaft”, „Przegląd Filozoficzno-Literacki” 2009, nr 2, s. 204-207.

34 J. Roth, Döblin na Wschodzie, dz. cyt., s. 50. Dlatego również opinia Todorowa, jakoby Roth zarzucał Döblinowi „nieznajomość tematu”, wydaje mi się oparta na nieporozumieniu. A. Todorow, Brechungen. Joseph Roth und das Feuilleton der „Frankfurter Zeitung” [w:] Joseph Roth. Interpretation - Kritik - Rezeption, dz. cyt., s. 375.

35 J. Roth, Żydzi na tutaczce, dz. cyt., s. 15.

36 J. Roth, Döblin na Wschodzie, dz. cyt., s. 50. 
swoich wrażeń, z tego, co zobaczył, usłyszał lub przeczytał. On także opowiada o emocjach, ale przede wszystkim o swoich własnych.

Inna teza Gelbera, którą przejął Michael Brenner w swojej znanej książce The Renaissance of Jewish Culture in Weimar Germany, jest również nieprzekonująca. Według Brennera: „Roth szybko starał się nadrobić to, czego Döblinowi - w jego oczach - nie udało się uchwycić” 37 , ponieważ „zachodnioeuropejska pycha cywilizacyjna” przeszkadzała Döblinowi „przedstawić rzeczywistość Żydów ze Wschodu" ${ }^{38}$. Jak już pokazałam, Roth w swojej recenzji Podróży po Polsce odniósł się z szacunkiem do Döblinowskiego opisu Żydów. Również zdaniem Davida Horrocksa, ze stawianego Döblinowi zarzutu zachodniej pychy i uprzedzeń Roth wyraźnie wyłącza jego obraz Żydów, przypisując mu wnikliwe spojrzenie na nich i sprawiedliwy osąd ${ }^{39}$. Jeżeli Roth polemizował z „zachodnimi poglądami” Döblina, nie czynił tego w Żydach na tułaczce, lecz w Listach z Polski, które, podobnie jak Döblin, inauguruje opisem podróży pociągiem z Berlina do Warszawy.

Obydwaj pisarze opisują nocne przekroczenie granicy i pierwsze wrażenia z Polski, uzyskane o świcie podczas obserwacji z okna pociagu. W obu wypadkach są to obrazy ubogiego wiejskiego życia: pola, bosa chłopka w białej chuście na głowie, stada bydła, gęsi (Döblin), chłopak pilnujący krów, kobiety z wiadrami, chłop w konnej furmance (Roth). Obrazy są podobne, lecz reakcje narratorów zgoła odwrotne. Döblin kończy ten fragment słowami: „Czuję skurcz w sercu. Otrząsam się" ${ }^{0}$. Stanowią one wyraz fizycznego, niemal odruchowego odrzucenia życia bliskiego naturze: dla Döblina, namiętnego mieszkańca metropolii, który w eseju Duch epoki naturalizmu wychwalał technikę jako kwintesencję współczesnej epoki realizującej się w miastach ${ }^{41}$, stanowiło ono regres do fazy rozwoju cywilizacji dawno już na Zachodzie przezwyciężonej. Swoiste pendant do tego wzdrygnięcia się na widok agrarnej Polski zasygnalizowane zostało na początku podróży, jeszcze w Niemczech, przy lekturze nagłówka gazety, mówiącego o jednym z największych technicznych dokonań epoki, które umożliwi człowiekowi przezwyciężenie ziemskiego ciążenia. Nagłówek brzmi Triumf zeppelina. Narrator czyta te słowa „z rosnącym gwałtownie lękiem, niemalże z bólem" ${ }^{42}$, czując, że teraz, podczas jazdy do Polski, żegna się z tą technicznie wysoko rozwiniętą kulturą.

37 M. Brenner, dz. cyt., s. 143 (tłum. M.B.).

${ }^{38}$ M.H. Gelber, dz. cyt., s. 130.

${ }^{39}$ D. Horrocks, The Construction of Eastern Jewry in Joseph Roth's Juden auf Wanderschaft [w:] Ghetto Writing: Traditional and Eastern Jewry in German-Jewish Literature from Heine to Hilsenrath, red. A. Fuchs, F. Krobb, Columbia, S.C. 1999, s. 119.

${ }^{40}$ A. Döblin, Podróż po Polsce, dz. cyt., s. 9.

${ }^{41}$ Tenże, Der Geist des naturalistischen Zeitalters (Dezember 1924) [w:] tegoż, Schriften zur Ästhetik, Poetik und Literatur, Frankfurt am Main 2013, s. 168-190.

${ }_{42}$ Tenże, Podróż po Polsce, dz. cyt., s. 8. 
Narrator Rotha obserwuje sceny z wiejskiego życia po przekroczeniu polskiej granicy nie z przestrachem, lecz z radością. Tkliwą miłość, jaką żywi wobec tego krajobrazu, przypisuje również samej przyrodzie, kiedy przedstawia „zieleniejące połacie kraju”, na których wierzby „rysowały się delikatnie na ciemniejszej zieleni ziemi i czule głaskały ją gałęziami”, czy „wózek, który lekko podskakuje”, oraz „srebrzyste lśnienie małej, powiewnej rodzinki brzóz” - „wszystko to dawało znaki oczom" ${ }^{\prime 3}$ - wszystko to jest też bliskie narratorowi i napawa go uczuciem spokoju. Podobnie jak Döblin Roth podkreśla w swoim tekście kontrast między gospodarką techniczno-przemysłową $\mathrm{i}$ agrarną, z podziwem opisując na początku pociąg pospieszny Paryż-Moskwa. Jest on dla narratora jednak nie tylko wyrazem technicznych możliwości człowieka, lecz stwarza też iluzję przyszłości, w której w Europie nie byłoby już dzielących granic narodowych:

Piękne białe tabliczki, na których dwa tak odległe światy jak Holandia i Rosja przedzielone są tylko kreską łącznika, wyglądają, jak gdyby podawały nie kierunek geograficzny, lecz czasowy, i wskazywały nie na Wschód, ale w przyszłość. (...) widok wagonu, który ma prawo bez wahania przejechać całą część globu, wystarczy, by wzniecić w nas przedwczesną dumę z rozumnego świata i owo fałszywe poczucie swobodnej, nieznającej przeszkód wędrówki ${ }^{44}$.

Później Roth rozbuduje jeszcze opozycję nowoczesność - przednowoczesność, rozciągając ją na ludzi, i tak na przykład w twarzach warszawskich dorożkarzy „nie naznacza się ów znamienny chłód bijący z technicznych fizjonomii, jakim u nas cechuje się nowy typ człowieka obeznanego z maszyną" ${ }^{45}$. Tą pochwałą życia bliższego naturze usiłuje przezwyciężyć zachodnie stereotypy na temat Europy Wschodniej i otworzyć spojrzenie zachodnioeuropejskiego obserwatora, które charakteryzuje też narratora u Döblina, na piękno Wschodu. Nie unika przy tym stereotypizacji Wschodu jako kultury przednowoczesnej, ale zmienia jej ocenę na pozytywną. Dodać należy, że jest to tylko jeden przykład redukcji „błędnych szablonów” i „haseł” na temat Polski oraz przekazu, który może przyczynić się do przełamania uprzedzeń i do wykształcenia „przyjaznego, życzliwego spojrzenia na ten kraj i zamieszkujących go ludzi" ${ }^{46}$. Przezwyciężenie zachodniego spojrzenia na Europę Wschodnią wykracza daleko poza polemikę z Döblinem i jest, jak pokazuje już początek serii artykułów Podróż po Galicjił ${ }^{47}$, ogólnym celem, do którego Joseph Roth dążył.

Ttum. Marek Szalsza

43 J. Roth, Listy z Polski, dz. cyt., s. 64.

${ }_{44}$ Tamże, s. 62.

${ }_{45}$ Tamże, s. 65.

46 Zob. A. Todorow, dz. cyt., s. 380.

${ }^{47}$ J. Roth, Podróż po Galicji, dz. cyt., s. 27. 


\section{Bibliografia}

Aschheim S.E., Brothers and Strangers. The East European Jew in German and German Jewish Consciousness, 1800-1923, Madison 1982.

Brandt M., „Podróż po Polsce” Alfreda Döblina. Kilka uwag o genezie tekstu, tłum. M. Szalsza, „Konteksty Kultury” 2017, z. 2.

Brenner M., The Renaissance of Jewish Culture in Weimar Germany, New Haven 1996.

Bronsen D., Joseph Roth. Eine Biographie, Köln 1974.

Döblin A., Der Geist des naturalistischen Zeitalters (Dezember 1924) [w:] tegoż, Schriften zur Ästhetik, Poetik und Literatur, Frankfurt am Main 2013.

Döblin A., Podróż po Polsce, tłum. A. Wołkowicz, Kraków 2000.

Dohrn V., Reise nach Galizien. Grenzlandschaften des alten Europa, Frankfurt am Main 1993.

Dziergwa R., Obraz Polski międzywojennej i konfrontacje z Kresami Wschodnimi II Rzeczypospolitej w utworach pisarzy niemieckich w latach 1918-1939, „Studia Historica Slavo-Germanica” 2004, t. 25.

Dziuba M., „To już prawie caty polski Lublin”. Zapiski Alfreda Döblina z podróży do Polski, „Scriptores. Pamięć. Miejsce. Obecnośc” 2003, nr 1 (27).

Gelber M.H., "Juden auf Wanderschaft" und die Rhetorik der Ost-West-Debatte im Werk Joseph Roths [w:] Joseph Roth. Interpretation - Kritik - Rezeption. Akten des internationalen, interdisziplinären Symposions 1989, red. M. Kessler, F. Hackert, Tübingen 1990.

Golec J., Literackie powroty do ojczyzny. Joseph Roth i jego Galicja [w:] tegoż, Od Wiednia do Czerniowiec. Galicja i Bukowina w wybranych niemieckojezycznych utworach literackich, Lublin 2017.

Górska U., Retoryka ekspresji i etyczny problem asymilacji. Rozważania wokót eseju Josepha Rotha "Juden auf Wanderschaft”, „Przegląd Filozoficzno-Literacki” 2009, nr 2.

Grynberg H., Postowie [w:] A. Döblin, Podróż po Polsce, tłum. A. Wołkowicz, Kraków 2000.

Horrocks D., The Construction of Eastern Jewry in Joseph Roth's Juden auf Wanderschaft [w:] Ghetto Writing: Traditional and Eastern Jewry in German-Jewish Literature from Heine to Hilsenrath, red. A. Fuchs, F. Krobb, Columbia, S.C. 1999.

"Jede Freundschaft mit mir ist verderblich". Joseph Roth und Stefan Zweig. Briefwechsel 1927-1938, Göttingen 2011.

Kwiecińska G., Z Alfredem Döblinem w Drugiej Rzeczypospolitej, „Literatura na Świecie" 1994, nr 6.

Matywiecki P., Początek podróży do końca, „Midrasz” 2001, nr 2.

Müller M., Konstruierte Distanz - Zu Joseph Roths erster Galizien-Reportage „Leute und Gegend" [w:] Joseph Roth und die Reportage, red. T. Eicher, Heidelberg 2010 . 
Nowak P., Ex oriente lux?, „Kronos. Metafizyka, kultura, religia” 2018, nr 1.

Raffel E., Vertraute Fremde. Das östliche Judentum im Werk von Joseph Roth und Arnold Zweig, Tübingen 2002.

Roth J., Listy z Polski, tłum. M. Łukasiewicz, wstęp K. Czyżewski, KrakówBudapeszt-Syrakuzy 2018.

Roth J., Żydzi na tutaczce, tłum. M. Łukasiewicz, wstęp A. Taborska, KrakówBudapeszt 2017.

Salvadori R., Döblin i Roth we Lwowie, „Zeszyty Literackie” 1999, z. 2.

Samotny wizjoner. Joseph Roth we wspomnieniach przyjaciót, esejach krytycznych $i$ artykutach prasowych, red. E. Jogałła, tłum. P. Krzak, Kraków-Budapeszt 2013.

Schöller W.F., Alfred Döblin. Eine Biographie, München 2011.

Sonino C., Exil, Diaspora, Gelobtes Land? Deutsche Juden blicken nach Osten, Ber$\operatorname{lin} 2002$.

Sternburg W. v., Joseph Roth. Eine Biographie, Köln 2009.

Sültemeyer-von Lips I., „Städte haben viele Gesichter”. Wieviel Fiktion vertragen Reportage und Feuilleton? [w:] Joseph Roth - Städtebilder: Zur Poetik, Philologie und Interpretation von Stadtdarstellungen aus den 1920er und 1930er Jahren, red. S. Pesnel, E. Tunner, H. Lunzer, V. Lunzer-Talos, Berlin 2016.

Todorow A., Brechungen. Joseph Roth und das Feuilleton der „Frankfurter Zeitung” [w:] Joseph Roth. Interpretation - Kritik - Rezeption, Akten des internationalen, interdisziplinären Symposions 1989, red. M. Kessler, F. Hackert, Tübingen 1990.

Wittlin J., Podróż Döblina po Polsce, „Wiadomości Literackie” 1927, nr 9. 